\title{
CROP FERTILIZER USE EFFICIENCY ANALYSIS (CFE): A Tool in identifying appropriate planting materials of coconut in different agro-climatic conditions
}

By

\author{
S.S. MAGAT ${ }^{1)}$
}

\begin{abstract}
Nine (9) sites with different growing conditions used in the Regional Testing of Promising Coconut Hybrids and Cultivars in the Philippines or MULTILOC Project (1985-1996) was subjected to the Crop Fertilizer Use Efficiency (CFE) Analysis. Two CFE indices were used CFEn = nut yield/kg fertilizer applied (per tree) and CFE $X=\mathrm{kg}$ copra yield $\mathrm{kg}$ fertilizers applied (per tree).

To a great extent, crop fertilizer use efficiency (CFE) ofsuperior hybrids grown in similar environments and appied with same moderate rates offertilizers have higher efficiency of converting the appliedfertilizers to economic yield, nuts or copra (measured in terms of CFEn and CFEc) compared to tall varielies tested in all MULTILOC sites (dry, intermediate and wet growing zone) at $\mathrm{n}$ ine years ftom field-planting (FP). The CFEs, CFEn (nut-based) at nine sites clearly differed in ternu of the first (best) five entries with highest CFE values. Explanation for this observation deserves further study, looking into the relationship of hybrid vigour (heterosis), crop morphology, physiology and yield.
\end{abstract}

Among the eleven (11) hybrid crosses, in terms of CFEn and CFEc, some of those which demonstrated wide suitabilityftom intermediate to wet growing conditions and environments, are: MRD x BAY, MRD x TAG, MRD x HJT, MRD x PJT, MYD x WAT The hybrid TAC x BAO dernonstrated impressive CFEs in Mindanao. Although most tall cultivars (Baybay, Laguna, Tagnanan, Mulanay, Loong, Lapasan and Hijo) at nine years from FP have still low value of CFEs compared to most hybrid crosses, with time (at leastfifteen years or more (full-bearing stage), the CFEs of these talls is likely to be higher and closer to superior hybrids.

The CFE analysis (index), either as CFEn (nutbased) or CFEc (copra-based) strongly appears to be a practical tool in identifying or screening hybrids and cultivars of coconut grown in different agro-climatic conditions. It directly indicates the yield (nuts or copra) per kg of fertilizer applied or invested over a period of time.

\section{INTRODUCTION}

In agricultural production, the key to maximum economic yield (MEY) is the right combination of planting materials, nutrition (fertilizers) and water or irrigation for specific growing environments of crops. This is widely applicable to coconut farming, be it at a small, medium or big scale one.

Aside from the genotypic and phenotypic bases used by plant breeders in screening appropriate varieties or hybrids, agronomist and crop nutritionist had studied the efficiency of utilizing the agricultural inputs supplied/applied to, the crop. These inputs could either be nutrients (i.e. N,P, K, etc), fertilizers (single or compound; organic or mineral), soil water or irrigation (volume or mm basis) etc.

\footnotetext{
${ }^{1}$ Scientist IV Philippine Coconut authority Agricultural R\&D Branch Diliman, Quezon City 1101.
} 
On bean crop (Phaseolus vulgaris L.), Malavolta and Amaral (1978), used Nutritional Eff iciency, E defined as yield/element absorbed by the crop. They found a strong positive correlation between $\mathrm{E}$ value and yield and claimed nutritional efficiency a useful parameter in the selection and/or screening of varieties.

Also, on corn inbreds (OPVs) and hybrids, the efficiency of phosphorus utilization in relation to yield under field conditions of these cultivars was reported to be a useful index in screening better planting materials (Fox, 1987). While on tornato, O' Sullivan et al (1974), claimed that also dry matter production (vegetative and fruits) of the crop indicated varied nutritional efficiency to nitrogen applied.

In the Coconut MULTILOC Project, as the common fertilizer applied to all entries supplied two or more nutrients (e.g. N, P, K, S, C1, Mg, B) at a moderate rate of fertilization (based on the annual leaf analysis of coconut samples), the average total amount of fertilizers for the last three years of the experiment was used in this analysis.

In this paper, the efficiency of utilization of fertilizers (CFE) applied to the tested cultivars and hybrids for a certain period of its development is defined by the rates:

(1) $\quad$ CFEn $=$ nut yield $/ \mathrm{kg}$ fertilizer applied $($ per tree $)$

(2) $\mathrm{CFEc}=\mathrm{kg}$ copra/yield $/ \mathrm{kg}$ fertilizer applied (per tree)

\section{MATERIALS AND METHODS}

\section{MULTILOC Sites}

The nine (9) sites located in either the dry, interinedlate and wet coconut growing zone of the country varied in soil conditions as indicated below.

\section{Entries of Cultivars and Hybrids}

There are seven (7) tall cultivars and eleven (11) crosses tested in the nine sites. These are indicated in box 2. The MYD and WAT hybrid and the Baybay tall were used as common entries in ail sites.

\section{Fertilizers applied}

For the analysis, the average total amount of fertilizers applied for the last three (3) years of the study was used (Table 3). It is considered that fertilizers applied during this period very likely influenced the yield performance of the reference year (1985). Fertilizers applied in ail MULTILOC sites (1986-1995) are presented in annex tables 1.1, 1.2 and 1.3.

\section{Yield Data}

In this analysis, the nut and copra yields for cropping 1995 (Table 4.1-4.9) obtained were used in computing the CFE, CFEn and CFEc respectively. The year 1995 (9 years from field planting) may be considered a year in which MULTILOC hybrid entries have reached initial full-bearing stage, especially those in wet growing zones (Guinobatan, Albay; Mambuaya, Cagayan de Oro; San Ramon, Zamboanga City and Tagum, Davao City). 
Compared to the MULTILOC sites in the dry zones and likely in some intermediate growing zones, the CFEs have reached the achievable values, either in terms of nuts (CFEn) or copra (CFEc).

\begin{tabular}{|c|c|c|c|c|c|}
\hline \multicolumn{6}{|c|}{ Box 1. Growing zones and soil conditions of the nine (9) MULTILOC } \\
\hline \multirow[b]{2}{*}{ Sites } & \multirow[b]{2}{*}{$\begin{array}{l}\text { Growing Zone/ } \\
\text { Climatic type }\end{array}$} & \multicolumn{4}{|c|}{ Soil Condition } \\
\hline & & Landform & $\begin{array}{l}\text { Internal } \\
\text { Drainage }\end{array}$ & Soil Type & $\mathrm{pH}$ \\
\hline \multicolumn{6}{|l|}{ LUZON } \\
\hline 1. Piat, Cagayan (CSU) & $\begin{array}{l}\text { Dry/Type D-dry } \\
\text { (6 dry mos.) }\end{array}$ & Inland-upland & Poor to fair & Sandy & 5.7 \\
\hline $\begin{array}{l}\text { 2. Los Banos, Laguna } \\
\text { (UPLB) }\end{array}$ & $\begin{array}{l}\text { Intermediate/type-C } \\
\text { Moist (4.5 dry mos.) }\end{array}$ & Inland-upland & fair to good & Clay Loam & 5.9 \\
\hline $\begin{array}{l}\text { 3. Mulanay, Quezon } \\
\text { (farmer-cooperation) }\end{array}$ & $\begin{array}{l}\text { Intermediate/type-B } \\
\text { Humid ( } 3 \text { dry mos) }\end{array}$ & Inland-flat & fair to good & Clay & 5.9 \\
\hline $\begin{array}{l}\text { 4. Guinobatan, Albay } \\
\text { (PCA-ARC) }\end{array}$ & $\begin{array}{l}\text { Wet/type A-wet } \\
\text { (1.5 dry mos.) }\end{array}$ & $\begin{array}{l}\text { Inland-upland } \\
\text { (moderately } \\
\text { sloping) }\end{array}$ & good & $\begin{array}{l}\text { Sandy } \\
\text { Loam }\end{array}$ & 6.8 \\
\hline \multicolumn{6}{|l|}{ VISAYAS } \\
\hline $\begin{array}{l}\text { 5. Baybay-Leyte } \\
\text { (VISCA) }\end{array}$ & $\begin{array}{l}\text { Wet/type B-wet } \\
\text { Humid ( } 3 \text { dry mos) }\end{array}$ & $\begin{array}{l}\text { Coastal-upland } \\
\text { (hilly) }\end{array}$ & good & Clay & 5.8 \\
\hline $\begin{array}{l}\text { 6. Carmen, Bohol } \\
\text { (farmer-cooperator) }\end{array}$ & $\begin{array}{l}\text { Intermediate/type } \\
\text { B-Humid ( } 3 \text { dry } \\
\text { Mos) }\end{array}$ & inland-upland & good & Clay Loam & 4.7 \\
\hline \multicolumn{6}{|l|}{ MINDANAO } \\
\hline $\begin{array}{l}\text { 7. Mambuaya } \\
\text { Cag. De oro } \\
\text { (school-cooperator) }\end{array}$ & $\begin{array}{l}\text { Wet/type A-wet } \\
\text { (1.5 dry mos.) }\end{array}$ & $\begin{array}{l}\text { Inland-upland } \\
\text { Moderately } \\
\text { sloping }\end{array}$ & Good & Clay & 5.4 \\
\hline $\begin{array}{l}\text { 8. San Ramon, Zamb. } \\
\text { City (PCA-ZRC) }\end{array}$ & $\begin{array}{l}\text { Intermediate/type B } \\
\text { Humid }\end{array}$ & Coastal-flat & Good & $\begin{array}{l}\text { Sandy } \\
\text { Loam }\end{array}$ & 6.6 \\
\hline $\begin{array}{l}\text { 9. Tagum, Davao } \\
\text { Norte (TRRC-Hijo } \\
\text { Plantation) }\end{array}$ & $\begin{array}{l}\text { Wet/type A wet } \\
\text { (1.5 dry no) }\end{array}$ & Inland-flat & fair to good & Loam & 5.6 \\
\hline
\end{tabular}

\section{Computation of CFE}

To compute the CIFEs (nut or copra basis), TABLE 1 (Fertilizers applIed) and yield data (tables 4.1-4.9) were used. The two CFEs refer to the ratio of variables below, using the simple formula:

(1) $\mathrm{CFEn}=$ nut yield $/ \mathrm{kg}$ fertilizer applied (per tree)

(2) $\mathrm{CFEc}=\mathrm{kg}$ copra/yield $/ \mathrm{kg}$ fertilizer applied (per tree)

The value of CFEn is in nuts $/ \mathrm{kg}$ fertilizer, while that of CFEc is in $\mathrm{kg}$ copra $/ \mathrm{kg}$ fertilizer. 


\section{RESULTS AND DISCUSSION}

The CFEs computed based on the ratio of yield (nuts, copra) and the fertilizer applied in each of the MULTILOC sites are shown in Tables 4.1 -4.9. Also, the ranking of entries are shown in Box 2.1 for CFEn (nut yieldbased) and in box 2.2 for CFEc (copra yield-based).

MULTILOC Piat, Cagayan (CSU)

Situated in a dry growing zone and with vype D-Dry climate, the best entry in terms of CFEn and CFEc is MRDxHJT with CFEn $=9.20$ and CFEc $=1.98$ (Table 4.1). These low values may be strongly attributed to high water deficit in most years.

The first five entries (Boxes 3.1 and 3.2) ranking is indicated as follows:

CFEn: MPD x HJT > MYD x WAT > WAT x RIT > MRD x RIT > CAM x BAY

CFEc: $\quad$ MRD x HJT > MYD x WAT > WAT x RIT >CAM x BAY >MRD x RIT

MULTILOC Los Banos, Laguna (UPLB)

Located in an intennediate growing zone with a type $\mathrm{C}$ (moist) climate, the best entry in terms of CFEn and CFEc is TACxBAO with CFEn $=21.50$ and CFEc $=6.64$, followed by MRDxRIT $(\mathrm{CFEn}=19.1$ and $\mathrm{CFEc}=4.67$ (table 4.2). These seemingly low values which are unexpected perfonnance of palms in Laguna (a traditional coconut area) at nine years from field-planting (FP); may largely be due to poor level of farm management in some years. In addition, water deficit in some years could be another factor.

Boxes 3.1 and 3.2 indicate the ranking of the best five entries as follows:

CFEn: TAC x BAO > MRD x RIT > MYD x WAT > MRD x BAY >MRD x TAG

CFEc: TAC x BAO > MRD x RIT > MRD x BAY > MRD x TAG > MYD x WAT

The ranking sequence of CFEc slightly changes, notably that of MYD x WAT and MRD x TAG entries, mainly attributed to smaller fruits of MAWA compared to MRD x TAG hybrid.

Mulanay, Quezon (Sikat Nanadiego farm)

The site is situated in an intermediate growing zone with type B humid climate. At nine years from FP, the best entry in terms of CFEn is MRD x BAY $($ CFEn $=26.90)$ and MRD x TAG in terms of CFEc (=7.42) (table 4.3), suggesting that with similar nut yields MRDxTAG hybrid has bigger copra weight/nut thus the higher CFEc.

Ranking of the first five entries (boxes 3.1 and 3.2) are shown below.

CFEn: MRD x BAY > MRD x TAG > MRD x HJT > PGD x LUP > MYD x WAT

CFEc: MRD x TAG > MRD x BAY > MRD x HJT > PGD x LUP > BAY

The CFEs values could be expected to increase when entries reach more stable yield in years to come provided the good level of fann management is maintained. 
Baybay, Leyte (ViSCA)

This MULTILOC site is located in a coastal-upland (hilly) area of an intermediate growing zone of coconut with a type-B (humid) climate. The best entry is MRD x RIT (CFEn $=12.2 ;$ CFEc $=$ 3.02, followed by MRD x WAT in terins of CFEn (= 10.60) and TAC x BAY in terms of CFEc $(=2.79)$ (Table 4.4). Definitely, these CFEs are very low and this manybe largely attributed to irregular attention given to timely application of the recornmended fertilizers.

The ranking of the best five entries (Boxes 3.1 and 3.2) is indicated below:

CFEn: MRD x RIT > MYD x WAT > TAC x BAY > MRD x HJT > MRD x BAY

CFEc: MRD x RIT > TAC x BAY > MYD x WAT > CAM x BAY > MRD x BAY

Probably when palms reach at least 15 years of age and proper farm management practices followed paticularly balance nutrition, the CFEs values could be higher.

\section{Guinobatan, Albay (PCA-ARC)}

Situated in a wet growing zone and type A (Wet) climate of the Bicol region, its best entiy is MYD x WAT in terms of nuts (CFEn $=37.20)$ and MRD x BAY in terms of copra (CFEc $=9.16)$ (Table 4.5). The higher CFEc of MRD x BAY compared to MYD x WAT is highly due to the higher copra weight/nut or nut size of the former.

It strongly appears that entries particularly the hybrids have reached the initial full-bearing stage, while the Talls Baybay, Tagnanan and Laguna would likely attain it in the next five years.

The ranking of the first five entries (Box 3.1 and 3.2) at nine years from FP is as follows:

CFEn: MYD x WAT > MRD x BAY > MYD x RIT > MRD x RIT > CAM x BAY

CFEc: MRD x BAY> MRD x TAG> MYD x RIT > MRD x HJT> CAM x BAY

These results indicate that even if the CFEn is high as in the case of MYD x WAT, due to the small nut size or copra weight/nut, a hybrid cross may have a lower CFEc. Therefore, the choice of planting materials highly depend on the market or intended use of coconut.

\section{Carmen, Bohol (Farmer Gustavo Decasq)}

This MULTILOC site is situated in an intermediate growing zone with a type B (humid) climate of an inland-upland area of Bohol Islands (Central Visayas).

Of the entries (Table 4.6), at nine years from FP, MYD x WAT had the highestCFE interms of nuts (CFEn =17.80) while MRD x TAG the hight in CFEc $=(4.08)$ followed by MRD x RIT (CFEn $=15.20)$ and MRD x HJT $(\mathrm{CFEc}=4.03)$ on the basis of nuts and copra yields, respectively.

It strongly appears, the initial full-bearing has not been reached yet by the entries, even the hybrids. Likely, this is largely attributed in the delays of application of the proper fertilizers, particularly in the first 6-7 years from FP of palms. below:

The ranking (Boxes 3.1 AND 3.2) of the best five entries of the site follows the sequence 


\section{CFEn : MYD x WAT > MRD x RIT > MRD x HJT > MRD x TAG > MRD x BAY \\ CFEc: MRD x TAG > MRD x HJT > MRD x RJT > MYD x WAT > MRD x BAY}

\section{Mambuaya, Cagayan de Oro City (Barangay Elem. School)}

It is situated in an inland-upland (hilly) area classified as a wet growing area of coconut with a type B (humid) climate of Northern Mindanao.

In terms of CFEn (Table 4.7), MRD x HJT is the best entry (CFEn 33.90), followed very closely by MYD x WAT (CFEn = 33.60) while in terms of copra, the MRD x HJT has also the highest CFEc ( $=9.29)$ but MRD x BAY (CFEc $=8,36)$ ranks second. Again, the better ranking of MRD x BAY over MYD x WAT as far as CFEc is concerned may be largely due to the bigger nutsize (or copra weight/ nut) of the former.

The impressive high CFEs value of entries, both hybrids and talls at nine years from FP in this MULTILOC site is very likely due to the combination of the favorable climatic conditions and highly effective fertilizer application, resulting in balance nutrition of palms. In fact, at early years of palm growth, boron deficiency in the site was detected and subsequently corrected.

Indeed, for hybrids, CFEn $=30$ nuts $/ \mathrm{kg}$ fertilizer applied (annually) or CFEc $=8 \mathrm{~kg}$ copra/kg fertilizer applied is clearly attractive enough.

Ranking of the first five hybrids (Boxes 3.1 and 3.2) follows the sequence below.

CFEn: MRD x HJT > MYD x WAT > MRD x BAY > MYD x RIT > TAC x BAO

CFEc: MRD x HJT > MRD x BAY > TAC x BAO > MYD x WAT > MYD x BAY

\section{San Ramon, Zamboanga City (PCA-ZRC)}

This MULTILOC site is located in a coastal-flat area of Western Mindanao, classified an intermediate growing zone with a type $\mathrm{C}$ (moist) climatic condition. Of the entries (Table 4.8), TAC $\mathrm{x}$ BAO obtained the highest CFEs (CFEn $=29.70$ and CFEc $=9.25)$, closely followed by MYD $\mathrm{x}$ WAT $($ CFEn $=29.60)$ in tenns of nuts yield and CAM x BAY (CFEc 7.81$)$ in term s of copra.

Among the nine (9) sites, the soil in this one strongly appears to be of high fertility level, thus response to fertilizer application is not very clear in most years. As the site subjected to seasonal short-time surface flooding, likely mixing of topsoils of adjacent blocks of fertilized palms with that of unfertilized ones, hence almost uniform levels of soil productivity in the experimental blocks.

The ranking of best five entries (Boxes 3.1 and 3.2) are as follows:

CFEn: TAC x BAO > MYD x WAT $>$ MRD x HJT $>$ MRD x TAG $>$ CAM x BAY

CFEc: TAC x BAO >CAM x BAY > MRD x TAG > MYD x WAT > MRD x BAY 


\section{Tagum, Davao Norte (TRRC - Hijo Plantation)}

A MULTILOC site located in an inland-flat area classified as a wet growing zone with a type A (wet) climate in Southem Mindanao. Of the eleven (11) entries (Table 4.9) the best entry is MRD $\mathrm{x}$ BAY both in CFEn $(=28.40)$ and CFEc $=(8.78)$, nuts and copra terms, respectively. This was followed by MYD x RIT and MRD x TAG with CFEc of 7.56 and 7.40, respectively.

Among the sites, this site probably reached the initial full-bearing stage earlier than the other sites with high CFEs as PCA-ARC (Albay), Marnbuaya, Cagayan de Oro City and PCA-ZRC (Zamboanga City). Most likely this is attributed to highly favorable climatic and soil conditions, including balance nutrition as a result of timely and judicious fertilizer application. This is one of the sites which showed boron deficiency during the early years of palm growth and was easily corrected with borax application (20-30 g/tree). following:

As to the sequence of the best five entries (Boxes 3.1 and 3.2), the CFE analysis showed the

$$
\begin{array}{ll}
\text { CFEn: } & \text { MRD x BAY }>\text { MYD x RIT }>\text { MRD x TAG }>\text { MRD x HJT }>\text { MYD x WAT } \\
\text { CFEc: } & \text { MRD x BAY > MYD x RIT }>\text { MRD x TAG }>\text { MRD x HJT and TAC x BAO }
\end{array}
$$

These two basis have very similar sequences of the CFEs except the replacement of MYD $\mathrm{x}$ WAT by TAC $x$ BAO in the CFEc (copra-based) as a result of lower copra weight/nut or nut size of the MYD x WAT compared to the hybrid TAC x BAO which has higher copra weight per nut.

\section{CONCLUSIONS}

1) To a great extent, crop fertilizer use efficiency (CFE) of superior hybrids grown in similar environments and applied with same moderate rates of fertilizers have higher efficiency of converting the applied fertilizers to economic yield, nuts or copra (measured in terms of CFEn and CFEc) compared to tall varieties tested in all MULTILOC sites (dry, intermediate and wet growing zone) at nine years from field-planting (FP).

2) The CFEs, CFEn (nut-based) and CFEc (copra-based) of the entries in the nine (9) sites clearly differed in terms of the first (best) five entries with highest CFE values. Explanation for this observation deserves further study, looking into the relationship of hybrid vigour (heterosis), crop morphology, physiology and yield.

3) Among the eleven (11) hybrid crosses, in tenns of CFEn and CFEc, some of those which demonstrated wide suitability from intermediate to wet growing conditions and environments, are: MRDxBAY, MR,DxTAG, MRDxHJT, MRDxRIT, MYDxWAT. The hybrid TACxBAO demonstrated impressive CFEs in Mindanao.

4) Although most tall cultivars (Baybay, Laguna, Tagnanan, Mulanay, Loong, Lapasan and Hijo) at nine years from FP have still low value of CFEs compared to most hybrid crosses, with time (at least fifteen years of more full-bearing stage), the CFEs of these talls is likely to be higher and closer to superior hybrids.

5) The CFE analysis (index), either as CFEn (nut-based) or CFEc (copra-based) strongly appears to be a practical tool in identifying or screening hybrids and cultivars of coconut grown in different agro-climatic conditions. It directly indicates the yield (nuts or copira) per kg offiertilizer applied or invested over a period of time. 


\section{RECOMMENDATION}

The Crop Fertlizer Use Efficiency (CFE), either in CFEn (nutbased) or CFEc (copra-based) be used as one of the criteria or practical tools in selecting or identifying planting material of coconut in different growing environments or zones in the country. In this technique, same level of desired fertilizer application is applied to ail genetic materials tested in the site.

\section{ACKNOWLEDGEMENT}

To the Program Management Committee (PMC) of the coconut MULTILOC Project, for giving the author the opportunity to be a working Consultant of the project (1986-1995).

To the PCA-ZRC's Breeding and Genetics Division for providing the complete basic yield clatabase (1992-1995) which was used in this analysis of CFE.

To ail Study Leaders of the nine (9) MULTILOC Sites for their strong cooperation in following the annual fertilizer recommenclation, the best they can.

To Mr. Joselito Francisco, PCA-ARMD Secretary, for patiently attending to the word processing needs of the manuscript.

And finally to God, our Father Almighty, for giving the author, the wisdom and sound mind to finish this work for the interest of ail concerned. 


\section{REFERENCES}

Fox, R. H (1978). Selection for Phosphorus efficiency. Communications in Soll Science and Plant Analysis 9:13-37

Magat, S. S. (1995 b). Consultant's Report: Crop Nutrition and Soil Fertility Management. MULTILOC Project, PCA, Diliman, Quezon City Report No. 2/95 11 p

Magat, S. S. (1995 a). Consultant's Report: Crop Nutrition and Soil Fertility Management. MULTILOC Project, PCA, Diliman, Quezon City Report No. 2/95 11 p

Malavolta, E (1978) Nutritional Efficiency of 104 Bean Varieties (Phaseolus vulgaris L.) from Plant Nutrition 1978. Proceedings of the 8th International Colloqium on Plant Analysis and Fertilizer Problems, Auckland, New Zealand, 28 August - 1 September 1978. A. R. Ferguson, R. L. Bielecki, I. B. Ferguson (Eds) N.Z. DSIR Information Series No. 134. Wellington: Government Printer, 1978.

O' Sullivan, J; Gabelman, W. H.; Gerloff C. (1974) Variations in efficiency of nitrogen utilization in tomatoes (Lycopersicum esculentum Mill) grown under nitrogen stress. J. American Soc. Horti. Sc. 99: 543-547.

PCA and PCARRD (undated). Regional Testing of Promising Coconut Hybrids and Cultivars (MULTILOC). Phase IV Report, Diliman, Quezon City and Los Banos, Laguna. 75p. 


\begin{tabular}{|l|c|c|c|}
\hline \multicolumn{4}{|c|}{$\begin{array}{c}\text { Box 2. Entries of promising tall cultivars and hybrids tested in } \\
\text { the MULTILOC Sites (9), 1985-1995 }\end{array}$} \\
\hline \multicolumn{3}{|c|}{ Entry } & \multicolumn{3}{|c|}{ Cultivar and Parental Materials } \\
\cline { 2 - 4 } & Tall cultivar & Female parent & Male parent \\
\hline BAY & BayBay & - & - \\
LAG & Laguna & - & - \\
TAG & Tagnanan & - & - \\
MUL & Mulanay & - & - \\
LON & Loong & - & - \\
LAP & Lapasan & - & - \\
HJT & Hijo & - & - \\
MYD x WAT & - & Malayan Yellow Dwarf & West African Tall \\
MYD x RIT & - & Malayan Yellow Dwarf & Rennel Tall \\
Mrd x RIT & - & Malayan Red Dwarf & Rennel Tall \\
MRD x TAG & - & Malayan Red Dwarf & Tagnanan Tall \\
MRD x BAY & - & Malayan Red Dwarf & Baybay Tall \\
MRD x HJT & - & Malayan Red Dwarf & Hijo Tall \\
TAC x BAO & - & Tacunan Green Dwarf & Bago-Oshiro Tall \\
PGD x LUP & - & Pacual Green Dwarf & Lupisan Tall \\
CAM x BAY & - & Camotes Green Dwarf & Baybay Tall \\
WAT x RIT & - & West African Tall & Rennel Tall \\
TAC x BAY & - & Tacunan Green Dwarf & Baybay Tall \\
\hline
\end{tabular}

1) Hybrids were produced by several participating agencies (PCA, ALL, TRRC, VISCA, UPLB) following either the controlled-pollination or assisted-pollination hybridization techniques. Raised in field nursery prior to field-planting.

\begin{tabular}{|l|c|c|c|c|c|}
\hline \multicolumn{5}{|c|}{$\begin{array}{c}\text { Box 3.1 The first five (5) ranking of MULTILOC Entries in nine (9) } \\
\text { Based of CFEn (nut yielding/kg of fertilizer applied) }\end{array}$} \\
\cline { 2 - 6 } \multicolumn{1}{|c|}{$\begin{array}{c}\text { MULTILOC } \\
\text { SITE }\end{array}$} & 1 & 2 & 3 & 4 & 5 \\
\hline $\begin{array}{l}\text { Piat, Cagayan } \\
\text { (CSU) }\end{array}$ & MRDxHJT & MYDxWAT & WATxRIT & MRDxRIT & CAMxBAY \\
\hline $\begin{array}{l}\text { Los Banos, Laguna } \\
\text { (UPLB) }\end{array}$ & TACxBAO & MRDxRIT & MYDxWAT & MRDxBAY & MRDxTAC \\
\hline $\begin{array}{l}\text { Mulanay, Quezon } \\
\text { (Farmer- } \\
\text { Cooperation) }\end{array}$ & MRDxBAY & MRDxTAG & MRDxHJT & PGDxLUP & MYDxWAT \\
\hline $\begin{array}{l}\text { Baybay, Leyte } \\
\text { (VISCA) }\end{array}$ & MRDxRIT & MYDxWAT & TACxBAY & MRDxHJT & MRDxBAY \\
\hline $\begin{array}{l}\text { Guinobatan, Albay } \\
\text { (PCA-ARC) }\end{array}$ & MYDxWAT & MRDxBAY & MYDxRIJ & MRDxHJT & CAMxBAY \\
\hline $\begin{array}{l}\text { Carmen, Bohol } \\
\text { (Farmer- } \\
\text { Cooperator) }\end{array}$ & MYDxWAT & MRDxRIT & MRDxHTJ & MRDxTAG & MRDxBAY \\
\hline $\begin{array}{l}\text { Mambuaya, } \\
\text { Cagayan de Oro } \\
\text { City (School- } \\
\text { Cooperator) }\end{array}$ & MRDxHJT & MYDxWAT & MRDxBAY & MYDxRIT & TACxBAO \\
\hline $\begin{array}{l}\text { San Ramon, } \\
\text { Zamboanga City } \\
\text { (PCA-ZRC) }\end{array}$ & TACxBAO & MYDxWAT & MRDXHJT & MRDxTAG & CAMxBAY \\
\hline $\begin{array}{l}\text { Tagum, Davao } \\
\text { Norte (TRRC-Hijo } \\
\text { Plantation) }\end{array}$ & MRDxBAY & MYDxRIT & MRDxTAG & MRDxHJT & MYDxWAT \\
\hline
\end{tabular}




\begin{tabular}{|l|c|c|c|c|c|}
\hline \multicolumn{5}{|c|}{$\begin{array}{r}\text { Box 3.2 The first five (5) ranking of MULTILOC Entries in nine (9) } \\
\text { Based of CFEn (kg copra yield/kg of fertilizer applied) }\end{array}$} \\
\cline { 2 - 6 } \multicolumn{1}{|c|}{$\begin{array}{c}\text { MULTILOC } \\
\text { SITE }\end{array}$} & 1 & 2 & 3 & 4 & 5 \\
\hline $\begin{array}{l}\text { Piat, Cagayan } \\
\text { (CSU) }\end{array}$ & MRDxHJT & MYDxWAT & WATxRIT & CAMxBAY & MRDxRIT \\
\hline $\begin{array}{l}\text { Los Banos, Laguna } \\
\text { (UPLB) }\end{array}$ & TACxBAO & MRDxRIT & MRDxBAY & MRDxTAG & MYDxWAT \\
\hline $\begin{array}{l}\text { Mulanay, Quezon } \\
\text { (Farmer- } \\
\text { Cooperation) }\end{array}$ & MRDxTAG & MRDxBAY & MRDxHJT & PGDxLUP & BAY \\
\hline $\begin{array}{l}\text { Baybay, Leyte } \\
\text { (VISCA) }\end{array}$ & MRDxRIT & TACxBAY & MYDxWAT & CAMxBAY & MRDxBAY \\
\hline $\begin{array}{l}\text { Guinobatan, Albay } \\
\text { (PCA-ARC) }\end{array}$ & MRDxBAY & MRDxTAG & MYDxHJT & MRDxHJT & CAMxBAY \\
\hline $\begin{array}{l}\text { Carmen, Bohol } \\
\text { (Farmer- } \\
\text { Cooperator) }\end{array}$ & MRDxTAG & MRDxHJT & MRDxRIT & MYDxWAT & MRDxBAY \\
\hline $\begin{array}{l}\text { Mambuaya, } \\
\text { Cagayan de Oro } \\
\text { City (School- } \\
\text { Cooperator) }\end{array}$ & MRDxHJT & MRDxBAY & TACxBAO & MYDxWAT & MYDxRIT \\
\hline $\begin{array}{l}\text { San Ramon, } \\
\begin{array}{l}\text { Zamboanga City } \\
\text { (PCA-ZRC) }\end{array}\end{array}$ & TACxBAO & CAMxBAY & MRDXTAG & MYDxWAT & MRDxBAY \\
\hline $\begin{array}{l}\text { Tagum, Davao } \\
\text { Norte (TRRC-Hijo } \\
\text { Plantation) }\end{array}$ & MRDxBAY & MYDxRIT & MRDxTAG & MRDxHJT & TACxBAO \\
\hline
\end{tabular}

\begin{tabular}{|l|c|c|c|c|c|}
\hline \multicolumn{7}{|c|}{$\begin{array}{c}\text { Table 3. MULTILOC Sites Average Total Rate of Fertilizers Applied } \\
\text { SITE }\end{array}$} & \multicolumn{5}{|c|}{ Kg Fertilizer (per tree/year) } \\
\cline { 2 - 6 } & 1993 & 1994 & 1995 & Total & Average \\
\hline Piat, Cagayan (CSU) & 2.50 & 2.00 & 3.00 & 7.50 & 2.50 \\
\hline $\begin{array}{l}\text { Los Banos, Laguna } \\
\text { (UPLB) }\end{array}$ & 3.90 & 3.00 & 0.75 & 7.65 & 2.55 \\
\hline $\begin{array}{l}\text { Mulanay, Quezon } \\
\text { (Farmer Cooperator) }\end{array}$ & 2.70 & 3.50 & 2.50 & 8.70 & 2.90 \\
\hline Baybay, Leyte (VISCA) & 2.50 & 3.25 & 2.75 & 8.50 & 2.83 \\
\hline $\begin{array}{l}\text { Guinobatan, Alaby } \\
\text { (PCA-ARC) }\end{array}$ & 3.50 & 2.50 & 3.00 & 9.00 & 3.00 \\
\hline $\begin{array}{l}\text { Carmen, Bohol (Farmer- } \\
\text { Cooperator) }\end{array}$ & 2.75 & 3.00 & 4.25 & 10.00 & 3.33 \\
\hline $\begin{array}{l}\text { Mambuaya, Cagayan de } \\
\text { Oro City (School- } \\
\text { Cooperator) }\end{array}$ & 4.00 & 3.00 & 3.50 & 10.50 & 3.50 \\
\hline $\begin{array}{l}\text { San Ramon, } \\
\text { Zamboanga City (PCA- } \\
\text { ZRC) }\end{array}$ & 2.95 & 2.75 & 3.25 & 8.95 & 2.98 \\
\hline $\begin{array}{l}\text { Tagum, Davao Norte } \\
\text { (TRRC-Hijo Plantation) }\end{array}$ & 4.50 & 4.40 & 4.25 & 13.15 & 4.38 \\
\hline $\begin{array}{l}\text { I) Combination or mixture of two or more fertilizer grades supplying nutrient needs. } \\
\text { (N, P, K, Cl, S, Mg, B). Specific fertilizer combination by sites shown in annex table 1. }\end{array}$ \\
\hline
\end{tabular}




\begin{tabular}{|c|c|c|c|c|c|c|c|}
\hline \multicolumn{8}{|c|}{$\begin{array}{c}\text { Table 4.1 Index of Crop Fertilizer Efficiency (CFE) of Entries in } \\
\text { MULTILOC-Piat, Cagayan (CSU) }\end{array}$} \\
\hline \multirow[b]{2}{*}{ Entry } & \multirow{2}{*}{$\begin{array}{c}\mathrm{Kg} \mathrm{FA}^{1} \\
\text { (av. 1993- } \\
95)\end{array}$} & \multirow{2}{*}{$\frac{\mathrm{N} / \mathrm{P}^{2}}{(1995)}$} & \multirow{2}{*}{$\frac{\mathrm{C} / \mathrm{P}^{3}}{(1995)}$} & \multicolumn{2}{|c|}{ CFE } & \multicolumn{2}{|c|}{ CFE RANK } \\
\hline & & & & CFE $n^{4}$ & CFE o ${ }^{5}$ & CFE $n$ & CFE o \\
\hline MYD x WAT & 2.5 & 22.5 & 4.96 & 9 & 1.98 & 2 & 2 \\
\hline MYD x RIT & 2.5 & 8 & 2.15 & 3.2 & 0.86 & 8 & 8 \\
\hline MRD x RIT & 2.5 & 11.5 & 2.81 & 4.6 & 1.12 & 4 & 5 \\
\hline MRD x TAG & 2.5 & 9.8 & 2.75 & 3.9 & 1.1 & 6 & 6 \\
\hline MRD x BAY & 2.5 & 8.4 & 2.26 & 3.4 & 0.9 & 7 & 7 \\
\hline MRD x HJT & 2.5 & 23 & 6.27 & 9.2 & 2.51 & 1 & 1 \\
\hline TAC $\times$ BAO & 2.5 & 0.6 & 0.19 & 0.2 & 0.08 & 10 & 11 \\
\hline PGD x LUP & 2.5 & 8.4 & 2.05 & 3.4 & 0.82 & 7 & 9 \\
\hline CAM x BAY & 2.5 & 10.1 & 2.84 & 4 & 1.14 & 5 & 4 \\
\hline WAT x RIT & 2.5 & 13.6 & 3.92 & 5.4 & 1.57 & 3 & 3 \\
\hline BAY & 2.5 & 1.8 & 0.5 & 0.7 & 0.2 & 9 & 10 \\
\hline
\end{tabular}

1. average Total weight of fertilizers applied

2. nut yield/tree/year in 1995 (mean of 2 replicates)

3. $\mathrm{kg}$ copra yield/tree/year in 1995 (mean of 2 replicates)

4. nuts/tree/kg fertilizer applied

5. kg copra/tree/kg fertilzier applied

\begin{tabular}{|c|c|c|c|c|c|c|c|}
\hline \multicolumn{8}{|c|}{$\begin{array}{l}\text { Table 4.2 Index of Crop Fertilizer Efficiency (CFE) of Entries in } \\
\text { MULTILOC-Los Banos, Laguna (UPLB) }\end{array}$} \\
\hline \multirow[b]{2}{*}{ Entry } & \multirow{2}{*}{$\begin{array}{c}\mathrm{Kg} \mathrm{FA}^{1} \\
\text { (av. 1993- } \\
95)\end{array}$} & \multirow{2}{*}{$\begin{array}{l}\mathrm{N} / \mathrm{P}^{2} \\
(1995)\end{array}$} & \multirow{2}{*}{$\begin{array}{c}\mathrm{C} / \mathrm{P}^{3} \\
(1995)\end{array}$} & \multicolumn{2}{|c|}{$\mathrm{CFE}$} & \multicolumn{2}{|c|}{ CFE RANK } \\
\hline & & & & $\mathrm{CFE} n^{4}$ & CFE o ${ }^{5}$ & CFE n & CFE o \\
\hline MYD x WAT & 2.55 & 42.40 & 9.40 & 16.60 & 3.69 & 3 & 5 \\
\hline MYD x RIT & 2.55 & 28.10 & 7.43 & 11.00 & 2.91 & 7 & 7 \\
\hline MRD x RIT & 2.55 & 48.67 & 11.91 & 19.08 & 4.67 & 2 & 2 \\
\hline MRD x TAG & 2.55 & 35.90 & 10.15 & 14.10 & 3.98 & 5 & 4 \\
\hline MRD x BAY & 2.55 & 40.60 & 10.90 & 15.90 & 4.27 & 4 & 3 \\
\hline MRD x HJT & 2.55 & 32.50 & 8.94 & 12.70 & 3.50 & 6 & 6 \\
\hline TAC x BAO & 2.55 & 54.90 & 16.94 & 21.50 & 6.64 & 1 & 1 \\
\hline PGD $x$ LUP & 2.55 & 23.90 & 6.06 & 9.40 & 2.38 & 8 & 10 \\
\hline CAM x BAY & 2.55 & 21.80 & 6.43 & 8.60 & 2.52 & 9 & 9 \\
\hline WAT $x$ RIT & 2.55 & 17.10 & 2.88 & 6.70 & 1.13 & 11 & 11 \\
\hline BAY & 2.55 & 21.70 & 3.45 & 8.50 & 2.53 & 10 & 8 \\
\hline
\end{tabular}

1. average Total weight of fertilizers applied

2. nut yield/tree/year in 1995 (mean of 2 replicates)

$3 . \mathrm{kg}$ copra yield/tree/year in 1995 (mean of 2 replicates)

4. nuts/tree/kg fertilizer applied

5. kg copra/tree/kg fertilzier applied 
Table 4.3 Index of Crop Fertilizer Efficiency (CFE) of Entries in MULTILOC-Mulanay, Qeuzon (Farmer-Cooperator)

\begin{tabular}{|c|c|c|c|c|c|c|c|}
\hline \multirow[b]{2}{*}{ Entry } & \multirow{2}{*}{$\begin{array}{c}\mathrm{Kg} \mathrm{FA}^{1} \\
\text { (av. 1993- } \\
95)\end{array}$} & \multirow{2}{*}{$\frac{\mathrm{N} / \mathrm{P}^{2}}{(1995)}$} & \multirow{2}{*}{$\frac{\mathrm{C} / \mathrm{P}^{3}}{(1995)}$} & \multicolumn{2}{|c|}{$\mathrm{CFE}$} & \multicolumn{2}{|c|}{ CFE RANK } \\
\hline & & & & $\mathrm{CFE} n^{4}$ & $\mathrm{CFE} 0^{5}$ & CFE $n$ & CFE o \\
\hline MYD x WAT & 2.70 & 50.20 & 11.08 & 18.60 & 4.10 & 5 & 7 \\
\hline MYD x RIT & 2.70 & 41.00 & 11.16 & 15.20 & 4.13 & 7 & 6 \\
\hline MRD x RIT & 2.70 & 44.10 & 10.88 & 16.30 & 4.03 & 6 & 8 \\
\hline MRD x TAG & 2.70 & 71.00 & 20.04 & 26.30 & 7.42 & 2 & 1 \\
\hline MRD x BAY & 2.70 & 72.60 & 19.90 & 26.90 & 7.37 & 1 & 2 \\
\hline MRD x HJT & 2.70 & 59.70 & 16.31 & 22.00 & 6.04 & 3 & 3 \\
\hline TAC x BAO & 2.70 & 54.70 & 13.90 & 20.20 & 5.15 & 4 & 4 \\
\hline PGD x LUP & 2.70 & 26.90 & 7.55 & 9.90 & 2.79 & 10 & 10 \\
\hline CAM x BAY & 2.70 & 39.20 & 11.71 & 14.50 & 4.34 & 8 & 5 \\
\hline WAT x RIT & 2.70 & 9.90 & 2.43 & 3.70 & 0.66 & 11 & 11 \\
\hline BAY & 2.70 & 38.90 & 9.45 & 14.40 & 3.50 & 9 & 9 \\
\hline
\end{tabular}

1. ave. Total weight of fertilizers applied

2. nut yield/tree/year in 1995 (mean of 2 replicates)

3. $\mathrm{kg}$ copra yield/tree/year in 1995 (mean of 2 replicates)

4. nuts/tree/kg fertilizer applied

5. $\mathrm{kg}$ copra/tree/kg fertilzier applied

\begin{tabular}{|l|r|r|r|r|r|r|r|}
\hline \multicolumn{7}{|c|}{ Table 4.4 Index of Crop Fertilizer Efficiency (CFE) of Entries in } \\
\hline \multirow{3}{*}{ Entry } & \multicolumn{2}{|c|}{ Kg FA $^{1}$} & \multicolumn{1}{|c|}{ N/P $^{2}$} & \multicolumn{1}{c|}{ C/P } & \multicolumn{2}{|c|}{ CFE } & \multicolumn{2}{|c|}{ CFE RANK } \\
\cline { 2 - 8 } & $\begin{array}{c}\text { (av. 1993- } \\
95)\end{array}$ & $(1995)$ & $(1995)$ & CFE n & CFE o & CFE n & CFE o \\
\hline MYD x WAT & 3.50 & 37.10 & 8.22 & 10.60 & 2.35 & 2 & 3 \\
MYD x RIT & 3.50 & 19.00 & 5.24 & 5.40 & 1.50 & 9 & 9 \\
MRD x RIT & 3.50 & 42.70 & 10.58 & 12.20 & 3.02 & 1 & 1 \\
MRD x TAG & 3.50 & 10.70 & 2.91 & 3.10 & 0.83 & 11 & 11 \\
MRD x BAY & 3.50 & 23.80 & 6.71 & 6.80 & 1.92 & 5 & 5 \\
MRD x HJT & 3.50 & 24.40 & 6.67 & 7.00 & 1.90 & 4 & 6 \\
TAC x BAO & 3.50 & 19.90 & 6.29 & 5.70 & 1.80 & 8 & 7 \\
PGD x LUP & 3.50 & 21.90 & 5.52 & 6.30 & 1.58 & 7 & 8 \\
CAM x BAY & 3.50 & 22.50 & 6.75 & 6.40 & 1.93 & 6 & 4 \\
WAT x RIT & 3.50 & 32.10 & 9.76 & 9.20 & 2.79 & 3 & 2 \\
BAY & 3.50 & 14.00 & 4.32 & 4.00 & 1.23 & 10 & 10 \\
\hline
\end{tabular}

1. ave. Total weight of fertilizers applied

2. nut yield/tree/year in 1995 (mean of 2 replicates)

3. $\mathrm{kg}$ copra yield/tree/year in 1995 (mean of 2 replicates)

4. nuts/tree/kg fertilizer applied

5. kg copra/tree/kg fertilzier applied 


\begin{tabular}{|l|c|c|r|r|r|r|r|}
\hline \multicolumn{7}{|c|}{ Table 4.5 Index of Crop Fertilizer Efficiency (CFE) of Entries in } \\
\hline \multirow{3}{*}{ Entry } & Kg FA $^{1}$ & \multicolumn{1}{c|}{ N/P $^{2}$} & \multicolumn{1}{c|}{ C/P } & \multicolumn{2}{|c|}{ CFE } & \multicolumn{2}{|c|}{ CFE RANK } \\
\cline { 2 - 9 } & $\begin{array}{c}\text { av. 1993- } \\
95)\end{array}$ & $(1995)$ & $(1995)$ & CFE n & CFE o & CFE n & CFE o \\
\hline MYD x WAT & 2.50 & 93.10 & 20.59 & 37.20 & 8.24 & 1 & 6 \\
MYD x RIT & 2.50 & 79.50 & 21.77 & 31.80 & 8.71 & 3 & 3 \\
MRD x RIT & 2.50 & 62.30 & 15.47 & 24.90 & 6.19 & 6 & 7 \\
MRD x TAG & 2.50 & 58.60 & 21.81 & 23.40 & 8.72 & 7 & 2 \\
MRD x BAY & 2.50 & 81.20 & 22.91 & 32.50 & 9.16 & 2 & 1 \\
MRD x HJT & 2.50 & 79.10 & 21.70 & 31.60 & 8.68 & 4 & 4 \\
TAC x BAO & 2.50 & 31.50 & 8.54 & 12.60 & 3.41 & 10 & 10 \\
PGD x LUP & 2.50 & 67.10 & 20.91 & 26.80 & 8.36 & 5 & 5 \\
CAM x BAY & 2.50 & 28.50 & 8.77 & 11.40 & 3.51 & 11 & 9 \\
WAT x RIT & 2.50 & 40.80 & 10.06 & 16.30 & 4.02 & 8 & 8 \\
BAY & 2.50 & 32.30 & 5.47 & 12.90 & 2.19 & 9 & 11 \\
\hline
\end{tabular}

1. ave. Total weight of fertilizers applied

2. nut yield/tree/year in 1995 (mean of 2 replicates)

3. $\mathrm{kg}$ copra yield/tree/year in 1995 (mean of 2 replicates)

4. nuts/tree/kg fertilizer applied

5. kg copra/tree/kg fertilzier applied

\begin{tabular}{|l|r|r|r|r|r|r|r|}
\hline \multicolumn{7}{|c|}{$\begin{array}{c}\text { Table 4.6 Index of Crop Fertilizer Efficiency (CFE) of Entries in } \\
\text { MULTILOC-Carmen, Bohol, (Farmer-Cooperator) }\end{array}$} \\
\hline \multirow{3}{*}{ Entry } & Kg FA $^{1}$ & \multicolumn{1}{|c|}{ N/P $^{2}$} & \multicolumn{1}{c|}{ C/P } & \multicolumn{2}{|c|}{ CFE } & \multicolumn{2}{|c|}{ CFE RANK } \\
\cline { 2 - 8 } & $\begin{array}{c}\text { (av. 1993- } \\
95)\end{array}$ & $(1995)$ & $(1995)$ & CFE n & CFE o & CFE n & CFE o \\
\hline MYD x WAT & 2.75 & 48.90 & 10.80 & 17.80 & 3.92 & 1 & 4 \\
MYD x RIT & 2.75 & 21.90 & 5.97 & 8.00 & 2.17 & 6 & 6 \\
MRD x RIT & 2.75 & 41.80 & 10.80 & 15.20 & 3.93 & 2 & 3 \\
MRD x TAG & 2.75 & 39.80 & 11.23 & 14.50 & 4.08 & 4 & 1 \\
MRD x BAY & 2.75 & 36.30 & 10.06 & 13.20 & 3.66 & 5 & 5 \\
MRD x HJT & 2.75 & 40.50 & 11.08 & 14.70 & 4.03 & 3 & 2 \\
TAC x BAO & 2.75 & 17.90 & 2.58 & 6.50 & 2.03 & 7 & 7 \\
PGD x LUP & 2.75 & 0.80 & 0.30 & 6.30 & 0.10 & 11 & 11 \\
BAY & 2.75 & 5.50 & 1.57 & 2.00 & 0.57 & 8 & 8 \\
TAG & 2.75 & 2.30 & 0.57 & 0.80 & 0.21 & 10 & 9 \\
LOONG & 2.75 & 2.70 & 0.47 & 1.00 & 0.20 & 9 & 10 \\
\hline
\end{tabular}

1. ave. Total weight of fertilizers applied

2. nut yield/tree/year in 1995 (mean of 2 replicates)

3. $\mathrm{kg}$ copra yield/tree/year in 1995 (mean of 2 replicates)

4. nuts/tree/kg fertilizer applied

5. kg copra/tree/kg fertilzier applied 


\begin{tabular}{|c|c|c|c|c|c|c|c|}
\hline \multicolumn{8}{|c|}{$\begin{array}{l}\text { Table 4.7 Index of Crop Fertilizer Efficiency (CFE) of Entries in } \\
\text { MULTILOC-Mambuaya, Cagayan de Oro City (City-Cooperator) }\end{array}$} \\
\hline \multirow{2}{*}{ Entry } & \multirow{2}{*}{$\begin{array}{c}\mathrm{Kg} \mathrm{FA}^{1} \\
\text { (av. 1993- } \\
95)\end{array}$} & \multirow{2}{*}{$\frac{\mathrm{N} / \mathrm{P}^{2}}{(1995)}$} & \multirow{2}{*}{$\frac{\mathrm{C} / \mathrm{P}^{3}}{(1995)}$} & \multicolumn{2}{|c|}{$\mathrm{CFE}$} & \multicolumn{2}{|c|}{ CFE RANK } \\
\hline & & & & CFE $n^{4}$ & CFE o ${ }^{5}$ & CFE n & CFE o \\
\hline MYD x WAT & 4.00 & 134.40 & 29.69 & 33.60 & 7.42 & 2 & 4 \\
\hline MYD x RIT & 4.00 & 107.40 & 29.06 & 26.90 & 7.26 & 4 & 5 \\
\hline MRD x RIT & 4.00 & 84.90 & 20.94 & 21.20 & 5.23 & 7 & 7 \\
\hline MRD x TAG & 4.00 & 90.80 & 25.71 & 22.70 & 6.43 & 6 & 6 \\
\hline MRD x BAY & 4.00 & 121.10 & 33.43 & 30.30 & 8.36 & 3 & 2 \\
\hline MRD x HJT & 4.00 & 135.80 & 37.18 & 33.90 & 9.29 & 1 & 1 \\
\hline TAC $\times$ BAO & 4.00 & 96.10 & 30.11 & 24.00 & 7.53 & 5 & 3 \\
\hline PGD x LUP & 4.00 & 64.20 & 16.52 & 16.00 & 4.13 & 9 & 9 \\
\hline BAY & 4.00 & 67.50 & 20.80 & 16.90 & 5.20 & 8 & 8 \\
\hline TAG & 4.00 & 54.60 & 13.47 & 13.60 & 3.37 & 10 & 11 \\
\hline Lapasan & 4.00 & 53.90 & 16.35 & 13.50 & 4.09 & 11 & 10 \\
\hline
\end{tabular}

1. ave. Total weight of fertilizers applied

2. nut yield/tree/year in 1995 (mean of 2 replicates)

3. $\mathrm{kg}$ copra yield/tree/year in 1995 (mean of 2 replicates)

4. nuts/tree/kg fertilizer applied

5. kg copra/tree/kg fertilzier applied

\begin{tabular}{|c|c|c|c|c|c|c|c|}
\hline \multicolumn{8}{|c|}{$\begin{array}{c}\text { Table 4.8 Index of Crop Fertilizer Efficiency (CFE) of Entries in } \\
\text { MULTILOC-San Ramon, Zamboanga City (PCA-ZRC) }\end{array}$} \\
\hline \multirow[b]{2}{*}{ Entry } & \multirow{2}{*}{$\begin{array}{c}\mathrm{Kg} \mathrm{FA}^{1} \\
\text { (av. 1993- } \\
95)\end{array}$} & \multirow{2}{*}{$\frac{\mathrm{N} / \mathrm{P}^{2}}{(1995)}$} & \multirow{2}{*}{$\begin{array}{c}\mathrm{C} / \mathrm{P}^{3} \\
(1995)\end{array}$} & \multicolumn{2}{|c|}{ CFE } & \multicolumn{2}{|c|}{ CFE RANK } \\
\hline & & & & CFE $n^{4}$ & CFE o ${ }^{5}$ & CFE n & CFE o \\
\hline MYD x WAT & 2.98 & 88.20 & 19.49 & 29.60 & 6.54 & 2 & 4 \\
\hline MYD x RIT & 2.98 & 59.70 & 16.24 & 20.00 & 5.45 & 8 & 7 \\
\hline MRD x RIT & 2.98 & 47.60 & 11.76 & 15.90 & 3.95 & 11 & 10 \\
\hline MRD x TAG & 2.98 & 80.10 & 22.64 & 26.90 & 7.60 & 4 & 3 \\
\hline MRD x BAY & 2.98 & 68.60 & 19.23 & 23.00 & 6.45 & 6 & 5 \\
\hline MRD x HJT & 2.98 & 82.70 & 22.65 & 27.70 & 7.60 & 3 & 3 \\
\hline TAC x BAO & 2.98 & 88.50 & 27.58 & 29.70 & 9.25 & 1 & 1 \\
\hline PGD x LUP & 2.98 & 56.30 & 14.38 & 18.90 & 4.83 & 9 & 9 \\
\hline CAM x BAY & 2.98 & 77.00 & 23.29 & 25.80 & 7.81 & 5 & 2 \\
\hline WAT x RIT & 2.98 & 60.50 & 17.91 & 20.30 & 6.01 & 7 & 6 \\
\hline BAY x BAY & 2.98 & 51.90 & 15.71 & 17.40 & 5.27 & 10 & 8 \\
\hline
\end{tabular}

1. ave. Total weight of fertilizers applied

2. nut yield/tree/year in 1995 (mean of 2 replicates)

3. $\mathrm{kg}$ copra yield/tree/year in 1995 (mean of 2 replicates)

4. nuts/tree/kg fertilizer applied

5. $\mathrm{kg}$ copra/tree/kg fertilzier applied 


\begin{tabular}{|c|c|c|c|c|c|c|c|}
\hline \multicolumn{8}{|c|}{$\begin{array}{l}\text { Table 4.9 Index of Crop Fertilizer Efficiency (CFE) of Entries in } \\
\text { MULTILOC-Tagum, Davao Norte (TRRC-Hijo) }\end{array}$} \\
\hline \multirow[b]{2}{*}{ Entry } & \multirow{2}{*}{$\begin{array}{c}\mathrm{Kg} \mathrm{FA}^{1} \\
\text { (av. 1993- } \\
95)\end{array}$} & \multirow{2}{*}{$\frac{\mathrm{N} / \mathrm{P}^{2}}{(1995)}$} & \multirow{2}{*}{$\frac{\mathrm{C} / \mathrm{P}^{3}}{(1995)}$} & \multicolumn{2}{|c|}{ CFE } & \multicolumn{2}{|c|}{ CFE RANK } \\
\hline & & & & $\mathrm{CFE}{ }^{4}$ & $\mathrm{CFE} \mathrm{o}^{5}$ & CFE n & CFE o \\
\hline MYDxWAT & 4.38 & 97.80 & 21.66 & 22.30 & 4.94 & 5 & 6 \\
\hline MYDxRIT & 4.38 & 120.50 & 33.12 & 27.50 & 7.56 & 2 & 2 \\
\hline MRDxRIT & 4.38 & 86.10 & 21.21 & 19.60 & 4.84 & 6 & 7 \\
\hline MRDxTAG & 4.38 & 114.30 & 32.43 & 26.10 & 7.40 & 3 & 3 \\
\hline MRDxBAY & 4.38 & 124.50 & 38.48 & 28.40 & 8.78 & 1 & 1 \\
\hline MRDxHJT & 4.38 & 114.00 & 31.18 & 26.00 & 7.12 & 4 & 4 \\
\hline TACxBAO & 4.38 & 74.90 & 23.63 & 17.10 & 5.39 & 7 & 5 \\
\hline PGDxLUP & 4.38 & 60.40 & 15.50 & 13.79 & 3.54 & 9 & 10 \\
\hline BAY & 4.38 & 59.40 & 18.19 & 13.56 & 4.15 & 10 & 8 \\
\hline TAG & 4.38 & 70.60 & 17.42 & 16.12 & 3.98 & 8 & 9 \\
\hline HJT & 4.38 & 48.00 & 11.85 & 10.90 & 2.70 & 11 & 11 \\
\hline
\end{tabular}

1. ave. Total weight of fertilizers applied

2. nut yield/tree/year in 1995 (mean of 2 replicates)

$3 . \mathrm{kg}$ copra yield/tree/year in 1995 (mean of 2 replicates)

4. nuts/tree/kg fertilizer applied

5. kg copra/tree/kg fertilzier applied 


\begin{tabular}{|c|c|c|c|c|c|c|c|c|c|}
\hline \multicolumn{10}{|c|}{$\begin{array}{l}\text { Table } 1 \text { MULTILOC Sites Average Actual Kind and Rate of Fertilizers, } \\
\text { 1986-1985 }\end{array}$} \\
\hline \multirow{2}{*}{ MULTILOC SITES } & \multicolumn{9}{|c|}{ SINGLE FERTILIZER COMBINATION (per tree/year) } \\
\hline & AS & UREA & $\mathrm{KCl}$ & AP & SP & T14 & $\mathrm{NaCl}$ & Dol & Borax \\
\hline $\begin{array}{l}\text { 1. Piat Cagayan } \\
\text { (CSU) } \\
1986:\end{array}$ & & & & & & & & & \\
\hline Field-Planting (FP) & $150 \mathrm{~g}$ & - & $150 \mathrm{~g}$ & - & - & - & - & - & - \\
\hline 6-months after & $200 \mathrm{~g}$ & - & $250 \mathrm{~g}$ & - & - & - & - & - & - \\
\hline 1987 & $500 \mathrm{~g}$ & - & $600 \mathrm{~g}$ & - & - & - & - & - & - \\
\hline 1988 & $500 \mathrm{~g}$ & - & $775 \mathrm{~g}$ & - & $125 \mathrm{~g}$ & - & - & - & $10-20 \mathrm{~g}$ \\
\hline 1989 & $500 \mathrm{~g}$ & - & $650 \mathrm{~g}$ & - & $500 \mathrm{~g}$ & - & - & - & - \\
\hline 1990 & $0.75 \mathrm{~kg}$ & - & - & - & - & - & - & - & - \\
\hline 1991 & $0.60 \mathrm{~kg}$ & - & $0.75 \mathrm{~kg}$ & - & - & - & $0.65 \mathrm{~kg}$ & $0.70 \mathrm{~kg}$ & $14 \mathrm{~g}$ \\
\hline 1992 & $0.60 \mathrm{~kg}$ & - & $1.65 \mathrm{~kg}$ & $1.30 \mathrm{~kg}$ & - & - & - & . & - \\
\hline 1993 & - & - & - & - & - & $1.75 \mathrm{~kg}$ & $0.75 \mathrm{~kg}$ & - & $35 \mathrm{~g}$ \\
\hline 1994 & - & - & $1.00 \mathrm{~kg}$ & - & - & $2.00 \mathrm{~kg}$ & - & - & $50 \mathrm{~g}$ \\
\hline 1995 & - & - & - & - & - & $3.00 \mathrm{~kg}$ & - & - & $50 \mathrm{~g}$ \\
\hline TOTAL from FP & $3.80 \mathrm{~kg}$ & - & $5.82 \mathrm{~kg}$ & $1.30 \mathrm{~kg}$ & $625 \mathrm{~g}$ & $6.75 \mathrm{~kg}$ & $1.40 \mathrm{~kg}$ & $0.70 \mathrm{~kg}$ & $169 \mathrm{~g}$ \\
\hline $\begin{array}{l}\text { 2. Los Banos, } \\
\text { Laguna } \\
\text { 1986: }\end{array}$ & & & & & & & & & \\
\hline Field-Planting (FP) & - & - & - & - & - & - & - & - & - \\
\hline 6-months after & - & $66 \mathrm{~g}$ & - & - & - & - & - & - & - \\
\hline 1987 & - & $265 g$ & - & $500 \mathrm{~g}$ & - & - & - & - & - \\
\hline 1988 & $333 \mathrm{~g}$ & - & $400 \mathrm{~g}$ & - & - & - & - & - & - \\
\hline 1989 & $1.50 \mathrm{~kg}$ & - & $1.65 \mathrm{~kg}$ & - & - & - & - & - & - \\
\hline 1990 & $1.25 \mathrm{~kg}$ & - & $1.50 \mathrm{~kg}$ & - & - & - & - & - & - \\
\hline 1991 & $1.70 \mathrm{~kg}$ & - & $1.80 \mathrm{~kg}$ & - & $0.75 \mathrm{~kg}$ & - & - & - & - \\
\hline 1992 & $1.70 \mathrm{~kg}$ & - & $1.80 \mathrm{~kg}$ & - & $0.75 \mathrm{~kg}$ & - & - & - & - \\
\hline 1993 & $0.65 \mathrm{~kg}$ & - & $2.00 \mathrm{~kg}$ & $1.25 \mathrm{~kg}$ & - & - & - & - & $20 \mathrm{~g}$ \\
\hline 1994 & - & - & - & - & - & $3.00 \mathrm{~kg}$ & - & - & $50 \mathrm{~g}$ \\
\hline 1995 & - & $0.75 \mathrm{~kg}$ & - & - & - & - & - & - & $45 \mathrm{~g}$ \\
\hline TOTAL from FP & $7.13 \mathrm{~kg}$ & $1.08 \mathrm{~kg}$ & $9.15 \mathrm{~kg}$ & $1.75 \mathrm{~kg}$ & $1.50 \mathrm{~kg}$ & $3.00 \mathrm{~kg}$ & - & - & $115 \mathrm{~g}$ \\
\hline
\end{tabular}


Cont Table 1

\begin{tabular}{|c|c|c|c|c|c|c|c|c|c|}
\hline \multirow{2}{*}{ MULTILOC SITES } & \multicolumn{9}{|c|}{ SINGLE FERTILIZER COMBINATION (per tree/year) } \\
\hline & AS & UREA & $\mathrm{KCl}$ & AP & $\mathrm{SP}$ & T14 & $\mathrm{NaCl}$ & Dol & Borax \\
\hline $\begin{array}{l}\text { 3. Mulanay, } \\
\text { Quezon } \\
\text { 1986: }\end{array}$ & & & & & & & & & \\
\hline Field-Planting (FP) & $150 \mathrm{~g}$ & - & $150 \mathrm{~g}$ & - & - & . & - & - & - \\
\hline 6-months after & $200 \mathrm{~g}$ & - & $250 \mathrm{~g}$ & - & - & . & - & - & - \\
\hline 1987 & $500 \mathrm{~g}$ & - & $600 \mathrm{~g}$ & - & - & - & - & - & - \\
\hline 1988 & $400 \mathrm{~g}$ & - & $450 \mathrm{~g}$ & - & - & - & - & - & - \\
\hline 1989 & $1.00 \mathrm{~kg}$ & - & $1.20 \mathrm{~kg}$ & - & - & 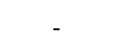 & - & - & - \\
\hline 1990 & $1.25 \mathrm{~kg}$ & - & $1.00 \mathrm{~kg}$ & - & - & - & - & - & - \\
\hline 1991 & $1.50 \mathrm{~kg}$ & - & $1.50 \mathrm{~kg}$ & - & - & - & - & - & - \\
\hline 1992 & $1.70 \mathrm{~kg}$ & - & $1.50 \mathrm{~kg}$ & - & - & - & - & - & - \\
\hline 1993 & $1.45 \mathrm{~kg}$ & - & $1.25 \mathrm{~kg}$ & - & - & $\begin{array}{l}- \\
-\end{array}$ & - & - & - \\
\hline 1994 & 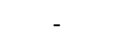 & - & $\begin{array}{lll}- & -\end{array}$ & - & - & $2.00 \mathrm{~kg}$ & - & $1.50 \mathrm{~kg}$ & - \\
\hline 1995 & - & - & - & - & - & $2.50 \mathrm{~kg}$ & - & 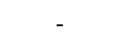 & - \\
\hline TOTAL from FP & $8.15 \mathrm{~kg}$ & - & $6.60 \mathrm{~kg}$ & - & - & $4.50 \mathrm{~kg}$ & - & $1.50 \mathrm{~kg}$ & - \\
\hline $\begin{array}{c}\text { 4. Guinobatan, } \\
\text { Albay (ARC) } \\
\text { 1986: }\end{array}$ & & & & & & & & & \\
\hline Field-Planting (FP) & $150 \mathrm{~g}$ & - & $150 \mathrm{~g}$ & - & - & - & - & - & - \\
\hline 6-months after & $200 \mathrm{~g}$ & - & $250 \mathrm{~g}$ & - & - & - & - & - & - \\
\hline 1987 & $500 \mathrm{~g}$ & - & $600 \mathrm{~g}$ & - & - & - & - & - & - \\
\hline 1988 & $750 \mathrm{~g}$ & - & - & $900 \mathrm{~g}$ & - & - & - & - & - \\
\hline 1989 & $1.50 \mathrm{~kg}$ & - & - & $1.80 \mathrm{~kg}$ & - & - & - & - & - \\
\hline 1990 & $1.25 \mathrm{~kg}$ & - & - & $1.50 \mathrm{~kg}$ & - & - & - & - & - \\
\hline 1991 & $0.71 \mathrm{~kg}$ & - & $1.40 \mathrm{~kg}$ & - & - & - & $0.65 \mathrm{~kg}$ & - & - \\
\hline 1992 & $0.75 \mathrm{~kg}$ & - & $1.50 \mathrm{~kg}$ & $0.60 \mathrm{~kg}$ & - & - & - & - & $40 \mathrm{~g}$ \\
\hline 1993 & $1.25 \mathrm{~kg}$ & - & - & - & - & - & $1.25 \mathrm{~kg}$ & - & - \\
\hline 1994 & $1.50 \mathrm{~kg}$ & - & - & - & - & - & - & - & - \\
\hline 1995 & $1.25 \mathrm{~kg}$ & - & $1.75 \mathrm{~kg}$ & - & - & - & - & $1.5 \mathrm{~kg}$ & - \\
\hline TOTAL from FP & $9.81 \mathrm{~kg}$ & - & $5.65 \mathrm{~kg}$ & $4.80 \mathrm{~kg}$ & - & - & $1.90 \mathrm{~kg}$ & $1.5 \mathrm{~kg}$ & - \\
\hline
\end{tabular}


Cont.........Table 1

\begin{tabular}{|c|c|c|c|c|c|c|c|c|c|}
\hline \multirow{2}{*}{ MULTILOC SITES } & \multicolumn{9}{|c|}{ SINGLE FERTILIZER COMBINATION (per tree/year) } \\
\hline & AS & UREA & $\mathrm{KCl}$ & $A P$ & SP & T14 & $\mathrm{NaCl}$ & Dol & Borax \\
\hline \multirow{3}{*}{\multicolumn{10}{|c|}{$\begin{array}{l}\text { 5. Baybay-Leyte } \\
\text { (ViSCA) } \\
\text { 1986: }\end{array}$}} \\
\hline & & & & & & & & & \\
\hline & & & & & & & & & \\
\hline Field-Planting (FP) & $150 \mathrm{~g}$ & - & - & - & - & - & - & - & - \\
\hline 6-months after & $200 \mathrm{~g}$ & - & - & - & - & - & - & - & - \\
\hline 1987 & $0.50 \mathrm{~kg}$ & - & - & - & - & - & - & - & - \\
\hline 1988 & $0.75 \mathrm{~kg}$ & - & - & - & - & - & - & - & - \\
\hline 1989 & $1.00 \mathrm{~kg}$ & - & - & - & - & - & - & - & - \\
\hline 1990 & $1.50 \mathrm{~kg}$ & - & $1.50 \mathrm{~kg}$ & - & - & - & - & - & - \\
\hline 1991 & $1.00 \mathrm{~kg}$ & - & - & $1.00 \mathrm{~kg}$ & $1.35 \mathrm{~kg}$ & - & - & - & - \\
\hline 1992 & $1.20 \mathrm{~kg}$ & - & - & - & - & - & - & - & - \\
\hline 1993 & - & - & - & - & - & $2.50 \mathrm{~kg}$ & $1.00 \mathrm{~kg}$ & - & - \\
\hline 1994 & - & - & - & - & - & $2.50 \mathrm{~kg}$ & - & - & $40 \mathrm{~g}$ \\
\hline 1995 & - & - & - & - & - & $3.00 \mathrm{~kg}$ & - & - & $50 \mathrm{~g}$ \\
\hline TOTAL from FP & $5.05 \mathrm{~kg}$ & - & $1.50 \mathrm{~kg}$ & $1.00 \mathrm{~kg}$ & $1.35 \mathrm{~kg}$ & $8.00 \mathrm{~kg}$ & $1.00 \mathrm{~kg}$ & - & $90 \mathrm{~g}$ \\
\hline \multicolumn{10}{|l|}{$\begin{array}{c}\text { 6. Carmen, Bohol } \\
\text { 1986: }\end{array}$} \\
\hline Field-Planting (FP) & $150 \mathrm{~g}$ & - & $150 \mathrm{~g}$ & - & - & - & - & - & - \\
\hline 6-months after & $200 \mathrm{~g}$ & - & $250 \mathrm{~g}$ & - & - & - & - & - & - \\
\hline 1987 & $500 \mathrm{~g}$ & - & $725 \mathrm{~g}$ & - & $600 \mathrm{~g}$ & - & - & - & - \\
\hline 1988 & $750 \mathrm{~g}$ & - & $900 \mathrm{~g}$ & - & - & - & - & - & - \\
\hline 1989 & - & - & - & - & - & - & - & - & - \\
\hline 1990 & $1.50 \mathrm{~kg}$ & - & $1.60 \mathrm{~kg}$ & - & $1.00 \mathrm{~kg}$ & - & - & - & - \\
\hline 1991 & $0.50 \mathrm{~kg}$ & - & $0.75 \mathrm{~kg}$ & - & - & - & $0.65 \mathrm{~kg}$ & $0.70 \mathrm{~kg}$ & $14 \mathrm{~g}$ \\
\hline 1992 & $0.50 \mathrm{~kg}$ & - & $0.75 \mathrm{~kg}$ & $0.65 \mathrm{~kg}$ & - & - & - & - & $14 \mathrm{~g}$ \\
\hline 1993 & - & - & - & - & - & $1.75 \mathrm{~kg}$ & $1.00 \mathrm{~kg}$ & - & $20 \mathrm{~g}$ \\
\hline 1994 & - & - & - & - & - & $2.00 \mathrm{~kg}$ & $1.00 \mathrm{~kg}$ & - & - \\
\hline 1995 & $1.25 \mathrm{~kg}$ & - & - & - & - & - & $1.50 \mathrm{~kg}$ & $1.50 \mathrm{~kg}$ & - \\
\hline TOTAL from FP & $9.81 \mathrm{~kg}$ & - & $4.10 \mathrm{~kg}$ & $0.65 \mathrm{~kg}$ & $1.60 \mathrm{~kg}$ & $3.75 \mathrm{~kg}$ & $4.15 \mathrm{~kg}$ & $2.20 \mathrm{~kg}$ & $48 g$ \\
\hline
\end{tabular}


Cont.......Table 1

\begin{tabular}{|c|c|c|c|c|c|c|c|c|c|}
\hline \multirow{2}{*}{ MULTILOC SITES } & \multicolumn{9}{|c|}{ SINGLE FERTILIZER COMBINATION (per tree/year) } \\
\hline & AS & UREA & $\mathrm{KCl}$ & AP & SP & T14 & $\mathrm{NaCl}$ & Dol & Borax \\
\hline \multicolumn{10}{|l|}{ 7. Mambuaya, } \\
\hline \multicolumn{10}{|l|}{$\begin{array}{c}\text { Cagayan de Oro } \\
\end{array}$} \\
\hline 1986: & & & & & & & & & \\
\hline \multicolumn{10}{|l|}{ Field-Planting (FP) } \\
\hline 6-months after & $200 \mathrm{~g}$ & - & $250 \mathrm{~g}$ & - & - & - & - & - & - \\
\hline 1987 & $500 \mathrm{~g}$ & - & $600 \mathrm{~g}$ & - & - & - & - & - & - \\
\hline 1988 & $1.00 \mathrm{~kg}$ & - & - & $1.10 \mathrm{~kg}$ & - & - & - & - & - \\
\hline 1989 & $0.50 \mathrm{~kg}$ & - & $0.75 \mathrm{~kg}$ & - & - & - & - & - & - \\
\hline 1990 & $0.75 \mathrm{~kg}$ & - & - & $1.50 \mathrm{~kg}$ & $1.00 \mathrm{~kg}$ & - & - & - & - \\
\hline 1991 & $0.50 \mathrm{~kg}$ & - & $1.30 \mathrm{~kg}$ & - & - & - & $60 \mathrm{~kg}$ & - & $18 \mathrm{~g}$ \\
\hline 1992 & $0.60 \mathrm{~kg}$ & - & $1.80 \mathrm{~kg}$ & - & $0.90 \mathrm{~kg}$ & - & - & - & $50 \mathrm{~g}$ \\
\hline 1993 & $1.50 \mathrm{~kg}$ & - & $1.50 \mathrm{~kg}$ & - & $1.00 \mathrm{~kg}$ & - & - & - & $40 \mathrm{~g}$ \\
\hline 1994 & - & - & - & - & - & $2.00 \mathrm{~kg}$ & $1.00 \mathrm{~kg}$ & - & $50 \mathrm{~g}$ \\
\hline 1995 & - & - & - & - & - & $2.50 \mathrm{~kg}$ & $1.00 \mathrm{~kg}$ & - & $50 \mathrm{~g}$ \\
\hline TOTAL from FP & $6.70 \mathrm{~kg}$ & - & $6.20 \mathrm{~kg}$ & $2.80 \mathrm{~kg}$ & $2.90 \mathrm{~kg}$ & $4.50 \mathrm{~kg}$ & $2.60 \mathrm{~kg}$ & - & $208 \mathrm{~g}$ \\
\hline 8. Tagum, Davao & & & & & & & & & \\
\hline Norter (TRRC) & & & & & & & & & \\
\hline 1986: & & & & & & & & & \\
\hline Field-Planting (FP) & $150 \mathrm{~g}$ & - & $150 \mathrm{~g}$ & - & - & - & - & - & - \\
\hline 6-months after & $200 \mathrm{~g}$ & - & $250 \mathrm{~g}$ & - & - & - & - & - & - \\
\hline 1987 & $500 \mathrm{~g}$ & - & $600 \mathrm{~g}$ & - & - & - & - & - & $20 \mathrm{~g}$ \\
\hline 1988 & $750 \mathrm{~g}$ & - & $850 \mathrm{~g}$ & - & - & - & - & - & - \\
\hline 1989 & $1.00 \mathrm{~kg}$ & - & $1.10 \mathrm{~kg}$ & - & - & - & - & - & - \\
\hline 1990 & $0.50 \mathrm{~kg}$ & - & $1.25 \mathrm{~kg}$ & - & - & - & - & - & - \\
\hline 1991 & $1.00 \mathrm{~kg}$ & - & - & - & - & - & $1.35 \mathrm{~kg}$ & - & $40 \mathrm{~g}$ \\
\hline 1992 & $1.00 \mathrm{~kg}$ & - & - & - & - & - & - & - & - \\
\hline 1993 & - & $0.50 \mathrm{~kg}$ & - & - & - & - & $2.50 \mathrm{~kg}$ & $1.50 \mathrm{~kg}$ & $40 \mathrm{~g}$ \\
\hline 1994 & - & $0.40 \mathrm{~kg}$ & - & - & - & - & $2.50 \mathrm{~kg}$ & $1.50 \mathrm{~kg}$ & $40 \mathrm{~g}$ \\
\hline 1995 & $1.25 \mathrm{~kg}$ & - & - & - & - & - & $1.50 \mathrm{~kg}$ & $1.50 \mathrm{~kg}$ & - \\
\hline TOTAL from FP & $5.35 \mathrm{~kg}$ & $0.90 \mathrm{~kg}$ & $4.20 \mathrm{~kg}$ & - & - & - & $7.85 \mathrm{~kg}$ & $4.50 \mathrm{~kg}$ & $1.40 \mathrm{~g}$ \\
\hline
\end{tabular}


Cont.........Table 1

\begin{tabular}{|c|c|c|c|c|c|c|c|c|c|}
\hline \multirow{2}{*}{ MULTILOC SITES } & \multicolumn{7}{|c|}{ SINGLE FERTILIZER COMBINATION (per tree/year) } \\
\cline { 2 - 9 } & AS & UREA & KCl & AP & SP & T14 & NaCl & Dol & Borax \\
\hline 9. Sn. Ramon, & & & & & & & & & \\
Zamboanga City & & & & & & & & & \\
(ZRC) & & & & & & & & & \\
1986: & & & & & & & & & - \\
Field-Planting (FP) & $150 \mathrm{~g}$ & - & $150 \mathrm{~g}$ & - & - & - & - & - & - \\
6 -months after & $200 \mathrm{~g}$ & - & $250 \mathrm{~g}$ & - & - & - & - & - & - \\
1987 & $500 \mathrm{~g}$ & - & $700 \mathrm{~g}$ & - & - & - & - & - & - \\
1988 & $600 \mathrm{~g}$ & - & $1.00 \mathrm{~kg}$ & - & - & - & - & - & - \\
1989 & $1.00 \mathrm{~kg}$ & - & - & $1.10 \mathrm{~kg}$ & - & - & - & - & - \\
1990 & $1.00 \mathrm{~kg}$ & - & $1.70 \mathrm{~kg}$ & - & - & - & - & - & - \\
1991 & $1.30 \mathrm{~kg}$ & - & $2.25 \mathrm{~kg}$ & - & $0.60 \mathrm{~kg}$ & - & - & - & $40 \mathrm{~g}$ \\
1992 & $1.12 \mathrm{~kg}$ & - & $2.50 \mathrm{~kg}$ & $1.00 \mathrm{~kg}$ & - & - & - & - & $60 \mathrm{~g}$ \\
1993 & - & $0.35 \mathrm{~kg}$ & $1.60 \mathrm{~kg}$ & $1.00 \mathrm{~kg}$ & - & - & - & - & - \\
1994 & - & - & - & - & - & $2.00 \mathrm{~kg}$ & $0.75 \mathrm{~kg}$ & - & $35 \mathrm{~g}$ \\
1995 & $1.25 \mathrm{~kg}$ & - & $2.00 \mathrm{~kg}$ & - & - & - & - & - & - \\
\hline TOTAL from FP & $7.12 \mathrm{~kg}$ & $\mathbf{0 . 3 5 \mathrm { kg }}$ & $12.15 \mathrm{~kg}$ & $3.10 \mathrm{~kg}$ & $\mathbf{0 . 6 0 \mathrm { kg }}$ & $2.00 \mathrm{~kg}$ & $\mathbf{0 . 7 5 \mathrm { kg }}$ & - & $135 \mathrm{~g}$ \\
\hline
\end{tabular}

AS (21-0-0); Urea (46-0-0); SP (0-20-0); AP (16-20-0); T14 (14-14-14); KCl (0-0-60); Nacl (Common Salt); DOL (camgC03-dolomite); Borax (11\% B) 